\title{
Saul Bellow's Seize the Day: A Modernist Study
}

\author{
Noorbakhsh Hooti \\ English Department, Faculty of Arts, Razi University, Kermanshah, Iran \\ Email: nhooti@yahoo.com \\ Vahid Omrani \\ English Department, Faculty of Arts, Lorestan University, Khoram Abad, Iran \\ Email: vahidomrani@yahoo.com
}

\begin{abstract}
This study tries to analyze Saul Bellow's Seize the Day from a modernist point of view. Bellow applies some narrative techniques which closely match those of the modernist diegetic process. The narrative has a potentially representative content which opens one's horizons toward new sources of meaning and conceptual interpretation. The focal point, in this study, is to examine the epistemological level, individualism, stream of consciousness, pessimism and irony to see how tangibly these terms agree with the very context of the above-mentioned novel and to find out whether the purely abstract terms extracted from modernist theory can be concretized in a practical form. Furthermore, this study aims at scrutinizing in detail the frequency and the possibility of the modernist narrative elements in the very fabric and texture of fictional narrative in general.
\end{abstract}

Index Terms — Saul Bellow, modernist, epistemology, individualism, irony

\section{INTRODUCTION}

The study starts with a brief introduction to modernism, modernist fiction, and a short analysis of Bellow's Seize the Day, which is followed by the modernist study of Seize the Day.

\section{MODERNISM}

Literary modernism is a twentieth-century movement which takes new aspects of literature, as concerned with the changing situation of the society, into account. The exact period in which the movement appeared is much debated by critics. Brooker argues that some critics extend the period from 1880 to 1950, while some others divide the period and "give priority to the prewar years," or" post-war years". (1972, p.4) some other critics believe that the movement started in 1890 and finished in 1945 when the second world war was over. The debate over the beginning or end of modernism is not as significant as its literary ideology which is to be discussed in this research.

Modernism as a "creative violence" (levenson, 2002, p.2) deviates from the literary tradition and turns the holistic and taken-for- granted literary concepts into new internal and mental trends. The significant point to be made here is that "modernist" must be distinguished from "modern". Modern can denote anything done or produced at the contemporary period while modernist refers to specific experimental elements which flout the conventional literary forms. In modern writings, the historical period is emphatically implied, whereas modernist writings lay stress on the dominant techniques and approaches which are deemed to be the touchstones for putting pen to paper.

Cuddon has given the following definition of modernism:

A very comprehensive term applied to international tendencies and movements in all the creative arts since the latter end of the $19^{\text {th }} \mathrm{c}$. Professor Kermode has made a distinction between Palaeo-modernism and Neo-modernism. Paleomodernism refers to early manifestations of new movements concluding, perhaps, c. 1914- 20, while neo-modernism refers to movements (like surrealism [q.v]) since that time. As far as literature is concerned modernism reveals a breaking away from established rules, traditions and conventions, fresh ways of looking at man's position and function in the universe and many ( in some cases remarkable) experiments in form and style. (1977, p. 399).

The above-mentioned citation can be clarifying and revealing as to the hallmarks of the movement. The modernist movement is "a breaking away form established rules" of the previous eras and considers "man's position" and" function" from a view point which is quite bizarre to the eyes of traditionalists. Modernism as "the literature of technology" displays "introversion, technical display, internal self-scepticism" (Bradbury and McFarlane, 1991, pp. 2627) to reflect "experiments in form and style" as man's roles and intellectuality change tremendously because of metropolitans and technological developments.

Another issue which instigated the modernist movement was the "nineteenth-century assumptions" which had established themselves as" dead conventions" (Faulkner, 1977, p. 1). Realism and naturalism were some of the touchstones by which the validity of literature was measured. But the modernists who regarded literature as a selfcontained phenomenon reflecting the autonomy of the writer disagreed over the well-established rules of the Victorian period and using experimental devices created new literary masterpieces based upon their own reflections and 
intellectualism.

They believed that "modernization has changed the very nature of reality" and literature "has to change its very nature" (Matz, 2004, p. 6) to dig up the unexcavated monuments of mind.

Ousby in his book called Literature in English came up with the following statement on modernism:

The term for an international tendency in the arts brought about by a creative renaissance during the last decade of the $19^{\text {th }}$ century and lasting into the post-war years. Strictly speaking, modernism can not be reliably characterized by a uniform style or even described as a "movement", since it embraced a wide range of artistic movements, including symbolism, impressionism, post-impressionism, Futurism, constructivism, Imagism, Vorticism, Expressionism, dada" and surrealism . (1996, p. 263)

As we can infer from this quotation, the renaissance that modernism follows is creative and we have a medley of different movements in modernism which point to it anti-realist and anti-traditionalist attributes. Thus, modernism which breaks with the past cannot reflect and underpin the flavor of traditional literature. It is revolutionary by nature and creates experimental backgrounds for the disintegration of man's mind and situation to match the modern environment in which consciousness is widely changed. It can mostly by ascribed to the modern era and the peculiarity of contemporary literary analysis. Therefore, it is not historically bound up with any particular period and challenges the conventions. Its aim is paradoxically gained through the literary devices and figures of traditional literature.

\section{MODERNIST FICTION}

As was mentioned before, modernism breaks with the past and the conventions of literary genres which were dominant in the previous eras. In the Victorian period, realism and 0naturalism were the outstanding modes in which the writers would arrange their novels. Verisimilitude as "the achievement of an illusion of reality in the audience" (Abrams, 1971, p. 211) was one of the main criteria to recognize literature as authentic. This aspect of fiction was mostly reflected in the realistic features of the novel.

Realist fiction attempted "to present life as it is" and naturalism gave "an even more accurate depiction of life than realism" in the eyes of Victorian novelist. Naturalism pointed to the deterministic aspects of life which are affected by "heredity and environment" (p. 174). Modernist fiction goes against the literary norms of the past by reflecting the internal aspects of each individual as autonomous subjects and defies the fate of man as determined through rendering " redemptive hope ' and " meaning or wholeness or beauty to the modern world' (Matz, 2004, p. 9)

An elaboration on "redemptive hope" can be unraveling through this quotation:

This redemptive conviction is typical, not universal: many modern novelists do not necessarily put the "pattern of hope into fiction." But for the mot part to write modern novels meant to face modernity with a sense that literary form could redeem it - that it could make a supreme difference to the very life of human culture. (p. 10)

The modernist fiction deals with the changing affects of technology and modernity in different ways. In so doing:

The modernist novel has shown, perhaps, four great preoccupations: with the complexities of its own form, with the representation of inward states of consciousness, with a sense of the nihilistic disorder behind the ordered surface of life and reality , and with the freeing of narrative art from the determination of an onerous plot. (Bradbury and McFarlane, 1991, p. 393).

Basically, the above-mentioned aspects may vary from novelist to novelist based upon the perspective they hold. In modernist fiction, the autonomy of the artist has been laid stress upon as significant. Therefore, to deviate from the literary norms of the fictionalization, each artist tries to portray the internal "complexities" of his world in an experimental way which is remarkably free form the "Linear narrative", and "logical and progressive order" typical of Victorian period. (p. 393)

Postmodernist fiction-writers can be divided into two groups: 1- traditionalist modernists and 2- new modernists which are discussed here to shed some light on the issue at hand. As Brooker says,

Virginia Woolf went on to suggest that modernist fiction had to do with a perception of changed social relations and attitudes; She applied "interiorizing treatment of character and consciousness in the novel but her method was not the method of modernism" for "she finds the 'modernist' Joyce and Eliot indecent and obscure (1972, p. 5).

The traditionalist modernism was a reaction against the classical literature which was still reminiscent of Victorian period while new modernism totally breaks with the previous conventions and compensates for the loss of identity through the reflection of new experimental techniques. To illuminate the traditionalist modernism the following quotation can be clarifying:

There were cross-references for this new classicism in literature, in Hulme, Eliot, Joyce, as well as Virginia Woolf, but again the claims and tendencies they pursued (for non-representationalism, impersonality of form and design, analogies across the arts or between art and science) were not in their own terms 'modernist'. (ibid, p. 6)

In reading different types of modernist fiction, we may unconsciously notice the above-mentioned qualities: because of the advent of movements such as 'symbolism', impressionism, 'post-impressionism', 'Imagism', dada, surrealism and so on, the new modernist fiction has been enhanced to a high extent but the role of forefathers as Virginia Woolf, T.S Eliot and James Joyce cannot be ignored.

In traditional Victorian novels, the role of narrative as crucial and well-established can be totally observed. The plot, characterization, point of view, denouement and other elements are flaunted in a naturalized way so that the readers 
who must sympathize with this trend of narrative writing find it impossible to escape the conventional narrative techniques. But as Woolf points out:

If a writer were a freeman and not a slave, if he could write what he chose, not what he must, if he could base his work up on his feeling and not upon convention, there would be not plot, no comedy, no tragedy, no love interest or catastrophe in the accepted style and perhaps not a single button sewn on as the bond Street tailors would have it. (qtd. in Reinhead, 2000, p. 2150)

As we can infer from the above-mentioned utterances, the process of free writing and individual-oriented narrative requires a deviation from "the accepted style" and the conventional narratives can not satisfy the demands of an everchanging individual in a world where the mentality of human beings is affected time and again by technological innovations and scientific progress.

In discussing modernist novels, we can point out their distinctions from conventional novels in terms of remarkably changed narrative techniques. The impact of Freudian psychology and the philosophy of Nietzsche and Marx on the mind of man turned his mind away from external objects and made him look into the internal affairs for which writers had not been able to find any appropriate outlets. In such circumstances, the conventional narrative techniques which mostly focused on external descriptions as the forming principles for narration did not suffice, so much so that modernist novelists turned to some bizarre processes which would portray man's mind and world in a defamiliarized manner.

In this way, experimentalism, as experiencing new forms and styles to satisfy modern man, came into existence. Modernists tried "to get beyond the over-simplified accounts of experience" and tested "new methods of organization" for their narratives" through juxtaposition (rather than simple narrative) and irony (rather than unity of mood)". (Faulkner 16). Here, the modernist narrative can be underpinned by what Joseph Frank calls "spatial form" in return for chronological form in the traditional art. (qtd. in Faulkner, 1977, p. 16) what Frank says has been elaborated on by Faulkner as saying that "the reader is being asked not to follow a story but to discern a pattern.... The tension between, 'the time-logic of language and the space-logic implicit in the modern conception of the nature of poetry'- and, as he also shows, of the novel.' (pp.16-17)

The "pattern" that is asked to be followed is mostly visualized through imagery and symbolism in poetry and as extended from poetry to modernist narratives; That is to say, if the reader is to decode modernist novels, he / she should go through the repetitive or thematic images or symbols as the keys to the designed plot of the novel which of course implies open-endedness and inconclusiveness for the reader who is suspended in a land of epistemological questions.

Narrative as opposed to naturalism and symbolism does not tend to encompass mimesis or poesis. As Trotter says "in modernist writing, mimesis is not so much an end in itself as and occasion for the triumph of poesis" (1999, pp. 75-76). So we have a "dialectic between the two doctrines. We can compare the modernist narrative to a detective story in which the more we go forward the more we get closer to its poetic aspects than imitation of bitter realities of life.

Narrative in modernist fiction can not follow and obey the conventional modes theorized by Aristotle and other critics because it is the portrait of and reflection of man's disintegrated mind which is finally resolved through "instilling into it a stricter form". (p. 74). The forms which are included in modernist narrative are mostly concerned with making the "self autonomous" (Nicholls, 1995, p. 251) and self-reflexive to cope with the technological modernity Modernist narrative " aims at making fiction itself as complex, as interesting and as strange as interesting and as strange as modern experience" ( Matz, 2004, p. 6).

In this part of the study, we would focus mainly on some of the techniques which are the building blocks for my research.

\section{A. Epistemological Level}

\section{According to Lacey:}

Epistemology also called theory of knowledge, occasionally gnoseology. Enquiry into the nature and grounds of knowledge. 'What can we know, and how do we know it?' are questions central to philosophy, and knowledge forms the main topic of epistemology, along with its relation to other cognitive notions like BELIEF, understanding, REASON, JUDGEMENT, SENSATION, PERCEPTION, INTUITION, guessing, learning, forgetting. (2005, p. 96)

The above-mentioned quotation elaborates about the philosophy behind this term to a large extent, but the roots of this movement in modernism are remarkably related to modern man's situation in the society. The alienation of modern man and his exposure to scientific development and new philosophical theories based on humanism made man wonder what the truth is and how he can achieve knowledge based on his limitations.

McHale talks about the epistemological doubts raised by modernist narratives and the kind of questions emphatically posed through these narratives. He says that:

Modernist fiction deploys strategies which engage and foreground questions such as ...: "How can I interpret this world of which I am a part? And what am in in it?... what is there to be known? Who knows it? How do they know it, and with what degree of certainty? How is knowledge transmitted from one knower to another, and with what degree of reliability? How does the object of knowledge change as it passes from knower to knower? What are the limits of the knowable? And so on. (1983, p. 9)

The significant point to be made about the above-mentioned strategies is that the modernist narratives put these problems forward either directly through questions or they implicitly raise them through the structure of their narratives 
or other relevant techniques which on the surface seem irrelevant, but in a closer reading unravel their coherence and interconnectedness. The pattern may be implied through the symbols or images prevalent in the story or the underlying structure which points to the epistemological foregrounding of the text at hand.

Taking the epistemological level into account, Matz comes up with the following comments on modernist narrative:

Who is speaking, and how, and why? What aspect of mental life is explored by the writer's choice of narrative levels? And, perhaps most importantly, how is the writer developing a unique mode of narration by combining different levelsby finding some unique way to move up and down the scale that runs from the most inward narration to the most outward? (2004, p. 58)

As we can see, Brain McHale and Jesse Matz have differently posed their questions, but the fact is that the essence is the same since the tow critics have observed the roles of limitedness and validity in their hypotheses. The only problem we face is that thy look at the issue from different perspectives. McHale has taken knowledge into consideration which is the source behind all information and Matz looks at "Narrative" and "narration" as the hallmarks for epistemological foregrounding. The quoted comments confirm the nature of modernist fiction itself owing to the fact that its variants take different aspects into account from the viewpoints of the writers but the essence, as based on the suspension of the novels, is the same.

In modernist narratives, "the omniscient narrator" was ruled out because the "third person voice, all-knowing and all seeing" could not fulfill the demands of epistemological dimension of narrations. So, instead a "limited point of view" was adopted to depict the subjectivity of the characters and their skeptical outlook in a world where " no real person ever gets the whole truth" (p. 51). In Saul Bellow's Seize the Day, the limited third person point of view is an indication of Tommy's bewilderment and indecisiveness in the social circumstances.

Brain McHale brings up the following themes as practical in foregrounding the epistemological dimension:

Accessibility and circulation of knowledge, the different structuring imposed on the "same" knowledge by different minds; and the problem of "unknowability" or the limits of knowledge: (P. 9)

Which are conveyed through the following devices:

The multiplication and juxtaposition of perspectives, the focalization of all the evidence through a single "center of consciousness"... virtuoso variants on interior monologue ..., "impeded form "(dislocated chronology, withheld or indirectly- presented information, difficult "mind-style" and so on. (ibid)

The above-mentioned factors are remarkably fruitful in instigating the epistemological level of modernist narratives, but the question which remains is: Does modernism find any answers to the raised questions? The modernist novels are open-ended and inconclusive and do not come up with denouements as we see in realist novels. In other words, they rebel against the established realistic norms; however, they create some alternatives for the problems of uncertainty and doubt through aesthetic forms. They produce "a new realism based strangely on doubt about reality itself" (p. 33)

\section{B. Individualism}

Individualism in modernist narratives reflects the artist's perspectives and views as against the conventional narrative norms; It is covered with "individual consciousness" (Matz, 2004, p. 58) of the artist as the focal point in the development of the literary representation. In other words, the inner world of the artist is preferred to the outer world of the society (Waugh, 1988, P. 24). This technique may stem from the art-for-art's sake philosophy in which the practicality of art as useful to the society and as harmonious with the social circumstances is rejected.

Another element which has been influential in the formation of individual is the alienation of man in the modern society where each individual takes refuge in his/ her own realm of existence.

The alienated modern man is deprived of his rights and demands. He is trapped in a society which determines his way of life and philosophy of being. So he takes refuge in himself, now we observe, as put forward by Maclntyre, what an alienated modern many may utter:

I am what I myself choose to be. I can always, if I wish to, put in question what are taken to be the merely contingent social features of my existence. I may biologically be my father's son; but I can not be held responsible for what he did unless I choose implicitly or explicitly to assume such responsibility. (2003, p. 560)

This "subjective, anti-social mind of the estranged individual" can "put in question" (Matz, 2004, P. 50) all the literary norms as genre, plot, point of view and so on since the prevailing norms can not meet man's demands in portraying the inner aspects of his world disintegrated by the complicated social backgrounds. But if the depiction of characters and their alienation goes too far, it may lead to paranoid, ambiguous personalities which are not discerned by ordinary readers of literary works. Waugh makes some comments in this regard:

In modernist fiction the struggle for personal autonomy can be continued only through opposition to existing social institutions and conventions. This struggle involves individual alienation and often ends with mental dissolution (1988, p. 10).

The modernist narrative of "the alienated human consciousness" leading to individualism had remarkable impacts on the readers. The new technique of "newness would take the world and make it strange" " it would require that people see it a new" and their aim was fulfilled through " defamiliarization" as put forward by "Victor Shklovsky"; "Virtually every work of modern fiction aims to defamiliarize" the norms to the audience. (qtd. in Matz, 2004, p. 71)

The alienation of man as the portrait of individualism was achieved through some steps of which the following two strategies are meticulously organized: 
The style of fiction became more poetically dense, as writers tried more self-consciously to place stranger weight on every word and every description. And, second, the fiction writer now set out self-consciously to shock; (Matz, 2004, pp. 71-72)

In Saul Bellow's Seize the Day the two elements as brought up above are delicately presented so that the alienation of modern man is skillfully displayed to the attentive readers who notice "the stranger weight" on every description of Tommy's misery by their willingness to be shocked.

\section{Stream-of-consciousness}

In modernist narrative, "loss of order" "led to the belief in its recovery at a deeper level of the mind" (Waugh, 1988, p. 24). They turned from the objective descriptive world of realism to the subjective personal world of the author. In this way, the traditional narrative techniques could not work any more; Modernists turned to "stream of consciousness" as an experimental strategy to delve into the mind of man as the ocean of knowledge. "Now human consciousness and especially artistic consciousness could become more intuitive, more poetic; art could now fulfil itself' (Bradbury and McFarlane, 1991, p. 25)

Stream of consciousness is a phrase coined by William James in his book called principles of psychology (1890). Abrams defines it as follows:

Stream of consciousness is the name for a special mode of narration that undertakes to reproduce, without a narrator's intervention, the full spectrum and the continuous flow of a character's mental process, in which sense perceptions mingle with conscious and half-conscious thoughts memories, expectations, feelings, and random associations (1971, p. 202)

The mingling of "sense perceptions" "with conscious and half-conscious" elements of human understanding may seem bizarre at first glance, but at a deeper level, all these metal processes interact to discover the "Epistemological cause" (Bradbury and McFarlane, 1991, p. 25) of human consciousness.

As was mentioned before the alienation of man from the society and the challenge of artists to be autonomous and independent were reflected in their efforts to produce unique and anti-realistic works. Stream of consciousness helped "several original minds" who "had been working, independently, towards a new method of writing fiction" prove their isolation and originality in the depiction of their loneliness and lack of communication. Modernists believed "no single view or style of explanation could ever by adequate to the diversity of modern experience"; Therefore," heterogeneity could be accounted for through the use of stream of consciousness as one of the diversifying techniques.

Stream of consciousness as the interpretive strategy of artistic independence can take many forms here what Matz says can be of great help:

Stream of consciousness could take many forms. The main goal- the "unmediated" discourse of the mid itself-could be reached in different ways depending on the state of mind in question or a writer's theory about where to locate the mind's most basic activity stream of consciousness might mean a very random jumble of perceptions and imagings, or it might mean a very direct pursuit of some train of thought, as long as its narration proceeds as if unprocessed by any authorial intervention. (2004, p. 54)

In Saul Bellow's seize the day, the second form rendered by Jesse Matz has been adopted so that "a very direct pursuit of some train of thought" is followed by Tommy Wilhelm as the main character in the novel. So the kind of misunderstanding about stream of consciousness as only collecting irrelevant perceptions of thought is demystified here, as opposed to other modernist narratives in which associations are mostly unrelated and randomized according to "multitudinous thoughts and feelings". (Cuddon, 1977, p. 661)

Stream of consciousness includes interior monologue as a subcategory or "interchangeably". Interior monologue is concerned with that species of consciousness which undertakes to present to the reader the course and rhythm of consciousness precisely as it occurs in a character's mind ( Abrams, 1971, p. 202)

Interior monologue is widely used in modernist narratives to foreground the epistemological level of characters' limitations (McHale, 1983, p. 9). This narrative strategy, the perceptions " would still not be wholly coherent, but they wouldn't descend so much into the irrational, the unconscious, or the nonverbal". (Matz, 2004: 56). The important point to be make here is that the writer "does not proceed" traditionally" with a view to bringing a continuity of exterior events to a planned conclusion" (Faulkner, 1977, p. 16). In this way, the traditional concepts of narrative and plot are shattered to reflect the epistemological complexities of modernist fictionalization.

The modernist narratives express a sense of pessimism in their attitudes throughout the narration. They mostly focus on this strategy because of their break with the previous pretensions of optimism. The role of urbanization and world wars cannot be ignored in this regard. Urban life and the impact of world wars made life complicated and hard to tackle. In this period, the writers flouted the conventional strategies of narrative and characterization to flaunt the disintegration of modern man. The role of alienation, which is the result of the isolation of man form a society in which lack of communication is widespread, can remarkably be observed in the pessimistic attitudes of modernists.

As we can observe, the perspective adopted here is that the "dysfunctional individual" cannot find his way in an "urban", "fragmented society". The above example is utterly existent in the characterization of Tommy Wilhelm in Saul Bellow's Seize the Day. The other point is that the epistemological bewilderment of characters in modernist narratives is caused by the innate pessimism of modernism as a key element in the formation of modernist paranoid personality.

Another key term closely related to pessimism in modernist narrative is paranoia. "Paranoia, or the threat of total 
engulfment by somebody else's system" is "keenly felt" by the modernist characters. (Lewis, 2001, p. 129). Here the skeptical paranoid characters who test truths and inquire into fundamentals, express their dissatisfaction, with life which does not work a certain way as against the Victorian narratives. The modernist characters are agonized by what Tony Tanner calls "dread that someone is patterning you life, that there are all sort of invisible plots a foot to rob you of your autonomy of thought and action, that conditioning is ubiquitous" (qtd.in Lewis, 2001, pp. 129-130)

The pessimistic modernist writers thought that the society was trying to Rob them of their "autonomy" and they had been conditioned by the traditional narrative techniques which had made them turn into anti- traditionalists. They believed in a general pessimism about the world, and rendered a rejection of society's certainties, a sense that only the artist is tells the truth. The reactions of modernist characterization in the development of this strategy can be fully elaborated in Bellow's work which will be discussed later on in the application section of the research under discussion.

\section{Irony}

Irony is defined as: "a statement in which the meaning that a speaker implies differs sharply from the meaning that is ostensibly expressed" (Abrams, 1971, p. 97). In modernist narratives, the role that irony plays can be quite remarkable because its function determines the way narration is distinguished from previous conventions. In modernist narrative, we no longer rely on " unity of mood" which orientates the readers' expectations, the "irony" of narratives makes the structures of modern narrations shattered and unpredictable so that the reader faces "juxtaposition" and not "simple narration" (Faulkner, 1977, p. 16).

In modernist narratives irony is used for different purposes, but one of the eye-catching justifications behind this technique is the epistemological level of modernism. Matz has more to say on that as follows:

And worst, if truth recedes entirely, if there is a great difference between lost truths and bad realities, irony results. Irony- the bleak difference between what is and what ought to be, the wry gap between what is said on the surface and what is really meant - is often the end-point of the modern novel, where questioning and skepticism lead ultimately to the dismal discovery that things are very much not what they $\operatorname{seem}(2004$, p. 34).

In modernist narratives, "writers also test reality by showing how much it is 'subjective'" (p. 23). Since the autonomy of the writers and their independence is revitalized only through the ironic distance they keep from the Victorian and realistic narratology. In realistic narratology, the events are naturalized and the readers are conditioned to follow the chronological or logical chain of events without taking the individuality of the characters into account, but modernist outlook toward narratology is uniquely constructed owing to its attentiveness to irony as the shelter from the past and "novels" which are "self-conscious about fiction's function" show "a new realism" directed at changing man's perception (p. 36).

Modernist narratives aim at flaunting realism ironically to show "aesthetic truth" (p. 77) as the alternative to the socially accepted realities. They usually pose some epistemological questions using ironic structures and the solution as opposed to realistic narratives turns ironically unexpected; consequently, a new form takes the place of traditionally accepted doctrines. They ironically break with the past to replace their subjective, epistemological creeds which are based on the internal world of the characters.

As opposed to realistic narratives, this modern novel does not begin describing the setting or mood according to literary norms, "It does not proceed from given starting point into a story", but it "works from the starting point to see how got there," (p. 33). The basis for the narration of Seize the Day is the epistemological foregrounding of realities as posed by the society and as perceived by the subjective character of Tommy Wilhelm.

In this study, the epistemological level, individualism, stream of consciousness, pessimism and irony as modernist techniques applicable to the novel are under discussion to see how these elements interact in conveying the message of modernist narration. The important point is that some of the above-mentioned elements may seem less obvious but the dominance of the techniques can be proved through a modernist reading.

\section{SEIZE THE DAY}

Seize the Day is a novel about Tommy Wilhelm who is an unemployed, middle-aged man who is waiting for a divorce from his nagging wife. He lives in Hotel Gloriana where he and his father live separately. He desperately needs his father's help, but he can never obtain it. The novel's narrative is confined to one day, but several flashbacks of Wilhelm's past are present. Wilhelm invests in trading lard and rye through Dr. Tamkin, a pseudo-psychologist. Tommy has problems with his wife and father which put him under pressure. Dr. Tamkin turns out to be a treacherous person and Tommy is deprived of his share in market, as a result. Dr. TAmkin offers the here and now philosophy to him and talks about the real soul and the pretender soul which make Tommy epistemologically confused. When he finds out about the destruction of his hopes, he goes to the street and accidentally attends a funeral in which he cries for the loss of another human being, himself and his inaccessible opportunities. The tears he sheds there are a catharsis for him and give him a new life of hope and happiness.

\section{A. The Epistemological Preoccupation of Tommy}

Tommy is constantly involved in a struggle with himself to see if he can find answers to the questions raised by his troubled life. Once his mother talked about Artie, wilkhelm's cousin. "who was an honor student at Columbia in math 
and languages". And what Tommy thought about him, as a result, can be put forward as follows: Did Artie love his languages, and live for them, or was he also, in his heart, cynical? So many people nowadays were, No one seemed satisfied and Wilhelm was especially horrified by the cynicism of successful people (Bellow, 1977, p. 20- henceforth Bellow)

Here, some philosophical questions concerning "cynicism" are problematically raised to foreground the epistemological preoccupations of Tommy as the protagonist of the novel. The narrative voice which follows the questions endorses Tommy's comments but its reliability is under question and also the shift in point of view makes the narrator difficult to read and brings about the question of how to deal with Wilhelm.

In another part of the novel, Tommy asks himself "when do you start to become a man?" (p. 19). This comment epistemologically points to the suspension and bewilderment that Tommy's character as a paranoid identity ascribes to himself. He later on asks himself "How could I have been such a jerk as not to prepare for anything and just go on luck and inspiration? (p. 19). This epistemological questioning in the form of an interior monologue gives more credence to Tommy's changing character as a modern man.

Epistemological doubt as a dominant mode can be traced throughout the narrative; Tommy is deprived of so many rights, encounters some mental, epistemologically posed questions which are typical of modern man. Talking about his mother's death with his father he says "yes, that was the beginning of the end, wasn't it, Father?"(p. 33)

Afterwards the third person narrator says:

Wilhelm often astonished Dr. Adler. Beginning of the end? What could be mean - what was he fishing for? Who's end? The end of family? The old man was puzzled but he would not give Wilhelm an opening to introduce his complaints. He had learned that it was better not to take up Wilhelm's strange challenges. (p. 33)

Wilhelm as the symbol of modern man, problematizes the concept of death for which no answer or solution is offered up to this part. His preoccupation with philosophical issues complicates his personality.

Tommy's sense of bewilderment is evident in his daily life in criticizing his father's behavior toward him, he says:

Why did I come here in the first place, to live near him? New York is life a gas. The colors are running. My head feels so tight. I don't know what I'm doing, He thinks I want to take away his money or that I envy him. He doesn't see what I want. (p. 55)

In this excerpt, his lack of knowledge concerning the social environment around him is underpinned through the monologue as one of the techniques in conveying epistemological doubt (McHale,1983, p. 8).

"The multiplication and juxtaposition of perspectives" (p. 9) In Saul Bellow's Seize the Day is associated with the epistemological foregrounding. The way Dr. Tamkin talks about life is different from the way Dr. Adler, Mr. Perls, or Tommy consider life. Tommy mostly blames his father, wife and urban life as the reasons behind his destruction, talking about city life he says:

Dad, I can't take city life anymore and I miss the country. There is too much push here for me. It works me up too much. I take things too hard. I wonder why you never retired to a quieter place. (Bellow, p. 49).

Later on his dad says:

You make too much of your problems, they ought not to be turned into a career. Concentrate on real troubles- fatal sickness, accidents. (p. 50)

As we can notice the medley of ideas leads to the dominance of epistemological limitations. We do not know who is right. Does Tommy as the protagonist come up with truth in emphasizing his subjective internal world? Does his father as the theorist of human external problems portray reality in the best way? The answer to these questions is not obvious, so it can "stimulate" us as readers towards the concept of "unknowability". (McHale, 1983, pp. 8-9)

A very interesting philosophical issue which is expressed through the third person narrator concerning Tommy goes on as follows:

Maybe the making of mistakes expressed the very purpose of his life and the essence of his being here. Maybe he was supposed to make them and suffer from them on this earth ...... and fall upon thorns of life. (Bellow, p. 61)

This comment made by the third person narrator is representative of Tommy's viewpoint. He is skeptically wondering whether "cosmic determinism" is the reason behind his destruction and questions "life" through his pessimistic metaphor of "thorns" as the actualization of his misery. But the adverb "maybe" again boosts his skepticism and bewilderment in the modern world.

\section{B. Stream of Consciousness}

This technique is mostly actualized in the form of interior monologue in this novel. As was mentioned before, the modernist writers use interior monologue to foreground their epistemological bewilderment (McHale,1983: 8). As we go through the context, Tommy's mental involvements are artistically displayed. His sense of confusion is mostly reflected in the way he describes the external objects according to his internal world as the decision-making touchstone in the formation of his personality. Describing his father's friend, Mr. Perls, Tommy comes up with the following comments: Who is this damn frazzle-faced herring with his dyed hair and his fish teeth and this drippy moustache? Another one of Dad's German friends? Where does he collect all these guys. (Bellow, p. 36)

As we can see, the interior monologue reflects the way Tommy considers the inner world as the basis for designing the external world and his subjective perspectives in his judgment on facial descriptions. In this novel; the role of interior monologue is multi-faceted. If you take Tommy into account, you will see how the interior monologues 
question his personality and the concept of self.

Tommy criticizes himself as offending his father and through the animal imaginary, he looks down on himself as a human being but the paradoxical point to be made about the interior monologues as opposed to the afore-mentioned comments is that Tommy is not always "forced to be extroverted". In other words his characterization cannot be described in the form of conventional modes; otherwise he could not be called a modernist character. His changing mood is aesthetically pointed out in the constant development of the interior monologues. In another part of the context as paradoxically oriented against the previous statements he says:

Dad thinks I'm too simple, but I'm not so simple as he thinks. He doesn't forget death for one single second, and that's what makes him feel like this. And not only is death on his mind but through money he forces me to think about it, too. It gives him power over me.(p. 62)

Here, Tommy fixes his faults on his father and seems to be an all-knowing man analyzing a faulty old father's personality in a psychologically proved manner. So his previous admittance of his faults is totally reflected through the justifications that are directed against his old man.

Seize the Day is a typically modern novel because its theme, Consciousness of selfhood, is centered on modernism. Tommy's Consciousness is a Conscious gesture that dignifies mankind even if it is fundamentally ridiculous .In realistic and Victorian novels. Characters are to a high extent types and they have the same attributes in different narratives, but here stream of Consciousness in the form of interior monologues helps the characters express their individuality and sense of loneliness. The realistic modes cannot meet the demands of modernist narratives because order, as was adopted by realism, does not exist anymore. The fragmentation of human personality must be shown according to a system which best matches the human Consciousness.

In seize the Day, the interior monologues are not chronologically created and do not follow the same pattern, but as opposed to other modernist novels in which the stream of Consciousness as free associations show the originality of modernism. It goes beyond human understanding; Seize the Day "is a very direct pursuit of some train of thought" (Matz, 2004, p. 54) in which interior monologues function as the proposers of the epistemological dimension of Tommy Wilhelm's mind. In realistic novels, the more we go forward the more the questions are solved for us. But here the more we move on, the more we encounter the epistemological questions posed by Wilhelm's monologues. As an example, we can refer to what Tommy says when he is offered a poem by Tamkin called: "Mechanism vs. Functionalism"(Bellow, p. 80) in which he does not associate the poem with some other events in his life' but "utterly confused, Wilhelm said to himself":

What kind of mishmash, claptrap is this! What does he give me this for? What's the purpose? Is it a deliberate test? Does he want to mix me up? ............ why do people naturally assume that you'll know what they are talking about? No, I don't know and nobody knows. (p. 81)

\section{Individualism}

In Seize the Day, the individuality of Tommy Wilhelm is ironically foregrounded. He has not been able to reach "individual Consciousness" (Matz, p. 58) because as against his wish, his father still calls him "Wilky" which seems childish and banal. Also, the descriptions expressed by Tommy about himself are mostly indicative of his inner world, as opposed to the outer world, in which he regards himself as " Fair- haired hippopotamus" (p. 10) in the form of animal imagery which is reminiscent of the sense of alienation from the society of human beings. The animal imagery mostly reflects lack of communication in modernist's novels owing to the fact that animals and human beings are not able to keep in touch mentally. They may have some physical confrontations but in the spiritual dimension, they are far apart and isolated because of the obstruction caused by technological developments and modern innovations.

There are a number of justifications behind individualism in this modernist narrative. Ciancio points to three elements. In the formation of individualistic leanings in Saul Bellow's Seize the Day .He talks about the "individual and his authentic self, the individual and contemporary urban world, the individual and humanity." Concerning the first one he refers to the "real and pretender soul" in the novel; The second element can be quoted as follows:

That sick Mr. Perls at breakfast had said that there was no easy way to tell the sane from the mad, and he was right about that in any big city and especially in New York- the end of the world, with its complexity and machinery, bricks and tubes, wire and stones, holes and heights, and was everybody crazy here? What sort of people did you see? Every other man spoke a language entirely his own, which he had figured out by private thinking, He had his own idea and peculiar ways. If you wanted to talk about a glass of water, you had to start back with God creating the heavens and earth, the apple; Abraham, Moses and Jesus, ... after reviewing this and getting it all straight again you could proceed to talk about a glass of water. (1969, pp. 89-90)

The sarcastic comment about "a glass of water" clearly points out the alienation of man and lack of knowledge in modern urban world which is replete with obstructions. In addition, absurdity has been implicitly expressed .That talking about "God" and "creation" and the prophets has nothing to do with "a glass of water", confirms the issue of absurd inclinations.

The third element to be elaborated on as "the individual and the humanity" has been clarified by Tommy: once in the market, he was in need of an old man's help, which could be even in the form of a gesture but:

It was not in the code to give information to anyone. Sick with desire, Wilhelm waited for Mr Rappaport to make an exception in his case. Just this one! Because it was critical. Silently, by a sort of telepathic concentration, he begged the 
old man to speak the single word that would save him, give him the merest sign. Oh, please -please help. If Rappaport would close one eye or lay his head to one side, or raise, his finger and point to a column in the paper or to a figure on his pad, A hint! A hint!(p. 94 )

Here, Tommy does not expect too much of the old man. He wants him to tell whether "lard" and "rye" will rise in the market, but the "code" of the business is to sacrifice everyone and think about your own self. In the last statement above, the misery of modern individuals has been utterly presented so that the isolation of humanity is delicately shown to emphasize the impact of modernity and human disintegration.

As was mentioned before, individualism raises the artist's views as against the literary narrative norms, to point out such perspectives, modernist narratives use some strategies: two of the strategies mentioned by Jesse Matz are to be applied here to the interpretation of Seize the Day; The first one is the "poetically dense" "style" of the authors "to place stranger weight on every word and description" as was explained before and the second one is the attempt "to shock self- consciously" (Matz, 2004, pp. 71-72)

Concerning the first one, the following excerpt can best present the discussion:

You have some purpose of your own, said the doctor. In acting so unreasonable. What do you want from me? What do you expect? What do I expect? Said Wilhelm. He felt as though he, were unable to recover something. Like a bal in the surf, washed beyond reach, his self-control was going out. 'I expect help! .... Wilhelm's hair, the color of whitened honey rose dense and tall with the expansion of his face, and he said. When I suffer - you aren't even sorry. That's because you have no affection for me, and you don't want any part of me. (Bellow, p. 58-59)

The second strategy can be elaborated on, as followers, Wilhelm asks the manager of a bank whether all his money goes to Dr, Tamkin according to their trade contract, and the manager says "No, it doesn't give him." Any rights. "only over, the funds I deposited with you,"(p. 66) he can trade. But we get shocked by what goes in Tommy's mind:

Thank you, that's what I wanted to find out; Wilhelm had said, grateful. The answer comforted him. However the question had no value. Not at all. For Wilhelm had no other assets. He had given Tamkin his last money.(ibid)

Here through the conversation between Bank manager and Tommy, we come closer to his sense of alienation and loneliness because he is trying to "shock" himself "self consciously" to get rid of his problems. Even the reader is affected by his policy and the sense of alienation becomes more logically obvious to the reader.

\section{Pessimism}

A sense of pessimism can be traced in the modernist narratives. They mostly focus on this strategy because of their break with the previous presentations of optimism. The role of urbanization and world wars can not be ignored in this regard because they make life complicated and hard to cope with. Consequently, the writers flouted the traditional literary strategies of narrative and characterization to flaunt the disintegration of modern man's life. Concerning the impact of urbanization the following excerpt can visualize the pessimistic viewpoints, Here is what Tommy says in response to his father's complaint in using pills:

No, Dad, it's not the pills, it's that I'm not used to New York anymore. For a native, that's very peculiar, isn't it? It was never so noisy at night as now, and every little thing is a strain. Like the alternate parking. You have to run out at eight to move your car. And where can you put it if you forget for a minute, they tow you away. Then some fool puts advertising leaflets under your wind shield wiper and you have heart failure a block away because you think you've got a ticket when you do get stung with a ticket, you can't argue. You haven't got a chance in court and the city wants the revenue. (Bellow, p.38)

The urban life led by Tommy and his father and living in a hotel has caused them lack of communication. Tommy is trying in vain to make sense of a predominantly urban and fragmented society. He also fixes his pessimism on his father. His paranoid attitudes maintain his pessimism:

But how we love looking fine in the eyes of the world how beautiful are the old when they are doing a snow job! It's Dad, thought Wilhelm, who is the salesman, he is selling me. He should have gone on the world. (p. 17)

In Seize the Day, There is "the conviction that society is conspiring against individual" (Lewis, 2001, p. 130) and the sense of paranoia in terms of Tommy Wilhelm's characterization in a modernist narrative can be conceived remarkably; Talking about "truth", Tommy says:

But what of the truth? Ah, the truth was that there were problems, and of these problems his father wanted no part. His father was a shamed of him. The truth, Wilhelm thought was very awkward. (Bellow, p. 17)

But Tommy's interpretation of "truth" does not go beyond the epistemological limitations nor does it lead to schizophrenia in which delusions about reality dominate the characters, to confirm, the above mentioned comments, The narrator can be quoted as follows:

But his memory was good, he could still separate what had been invented from the actual happening. (p. 19)

Tommy suspects that he" is trapped at the center of an intrigue, often with some justification." (Lewis, 2001, p. 130). He thought "that Dr Alder was using him" (36) and "thing were chaotic all over" (p. 37). His paranoid pessimism has been beautifully portrayed in the quotation below:

The spirit, the peculiar burden of his existence lay upon him like an accretion, a load, a hump, in any moment of quiet, when sheer fatigue prevented him from struggling, he was apt to feel this mysterious weight, this growth or collection of nameless things which it was the business of his life to carry about. That must be what a man was for. (Bellow, p. 44) 
Here, "the business of his life." To "carry about" his ideality as an alienated man in a bizarre world can imply his sense of epistemological pessimism because as he says: "that must be what a man was for." This comment is not reliably uttered and even the viewpoint behind it comes out of a paranoid, trembling man who has lost his sense of orientation in a world where values have changed and reliance upon other people is like hanging on the edge of a cliff.

In Seize the Day, the psychological tips of Dr Tamkin which finally turn against him as a liar maintain and support Tommy's pessimism to a high extent, he is actually the one who traps Tommy with the use of his intrigues, Tommy as an epistemologically confused man:

Was inclined to agree that many businessmen were insane. And he supposed that Tamkin, for all his peculiarities, spoke a kind of truth and did some people a sort of good. It confirmed Wilhelm's suspicions to hear that there was a plague, and he said, I couldn't agree with you more. They trade on anything. They steal everything. They're cynical right to the bones. (p. 69)

The interpretive point to be made about the quotation is that there is an ironic sense and the reader is directed toward an unbelivability in Tommy's exaggerated cynicism. A paranoid personality would generalize his personal trials and tribulations to mitigate his pains. This characteristic is obviously marked in Tommy's comments. But also it is typical of modernist characterization and changing social circumstances.

The ironic look at pessimism and its epistemological bewildering aspect reaches a point where "abandoning the intractable problems of attaining to reliable knowledge of our world" is dominantly observed and narratives "improvise a possible world" (McHale, 1983, p. 10).This perspective about modernism is specifically obvious in this novel and the aesthetic outlook as an alternative will be further discussed in the next section.

\section{E. Irony}

Throughout the novel, ironic structures are evident. First of all Tommy's, characterization has been ironically conducted as opposed to realistic novels in which the characters can be described in one single sentence and Tommy's changing mood has been ironically conveyed, in one section, we encounter the description that "Wilhelm was used to active life and liked to go out energetically in the morning. (p. 8). As ironical to the previous description, we see that "he had put forth plenty of effort but that was not the same as working hard, was it? The contraction between the two comments leads us to epistemological bafflement and points to the fact that he can not be restricted to a single description of personality.

The function of irony in modernist narratives is also concerned with the epistemological doubt. Modernist novelists use the following four testing strategies as concerned with irony to reach their goals:

Modern novelists tend, First of all, to concern themselves, with difference between appearance and reality. Second, they tend to wonder about subjective and objective perception. They search for essential meanings, in the hope that these might replace the structures and custom that modernity has destroyed. Andy finally modern novelists begin to become self-conscious about the way fiction works as a form for mediation or interpretation of reality. (Trotter, 1999, p. 34).

All the above-mentioned factors have been put forward in Saul Bellow's Seize the Day with the use of irony. For example the difference between appearance and reality" in the ironic pessimism of the narration is evident, Dr Tamkin says that:

If you only know one percent of what goes on in the city of New York !You see, I understand what it is when the only person begins to feel like an animal when the night comes and he feels like howling from his window like a wolf. (Bellow, p. 72)

Here, what Dr Tamkin says makes us more doubtful and we look at his statements ironically because as we go through the events we find out that he is not reliable.

Talking about "the pretender soul" and "the real soul" can ironically questions the "objective and subjective perception" (Matz, 2004, p. 34) of human beings in recognizing the essence of reality in modernism as opposed to realistic narratives. Dr Tamkin says:

The interest of the pretender soul is the same as the interest of the social life, the society mechanism. This is the main tragedy of human life, the society. Oh, It is terrible! terrible!..... The true soul is the one that pays the price.. It suffers and gets sick, and it realizes that the pretender soul can't be loved. Because the pretender soul is a lie. The true soul loves the truth. (Bellow, p. 76)

Tamkin, here, preaches something that he can not practices so the ironic aspects is revealed to the reader as they find about the treacherous intentions of the so-called Dr. Tamkin so much so that the ironic difference between the statements and fulfillments make the reader more epistemological bewildered.

The important point which has been ironically conveyed in Seize the Day is that through the ironic twist at the end "aesthetic truth" as the alternative to Tommy's problems is brought up. He cries for a human being in his funeral and participates in an aesthetic experience.

\section{CONCLUSION}

In this study, a number of modernist and postmodernist techniques were applied to Saul Bellow's Seize the Day and Kurt Vonnegut's Slaughter-House Five respectively to see how the shift from Modernism to Postmodernism can be 
accounted for in terms of literary development.

In Seize the Day, the epistemological dominant as proposed by McHale, was widely used throughout the novel. The important point is that the novel is replete with epistemological questions which are self-consciously crystallized. From the very beginning, this characteristic is evident; Therefore, McHale's proposition at least can be applied to this modernist novel.

The role of stream of consciousness as the focal point through which the autonomy and individuality of the author is conveyed, is also predominantly foregrounded so that thoughtful readers will notice its significance as soon as they start reading the novel.

Individualism has been expressed and actualized through the new outlook that we obtain in the context of Seize the Day. The unique and far-fetched descriptions of the protagonist as an antihero who does not appease the demands of conventional readers fortifies the anti-traditional dimension of modernism.

The use of irony in Seize the Day, is totally new in terms of structural patterns; Irony makes us aware of what we regard as true and what the contextualized truth refers to; This quality arouses the sense of epistemological questioning in the readers.

Pessimism as actualized in the form of paranoia is prevalent in Seize the Day .This technique mostly reflects the situation of Modern man as dismal and pathetic .Pessimism can be the offspring of modernization and technological innovations. The important point to be made here is that in Saul bellow's Seize the Day all the above-mentioned techniques are simultaneously existent in a chain-like manner. They eventually point to the dominance of epistemology in this modernist literary work. They interact together to problematize what the modern man is looking for as the final limit of knowledge.

The important point is that Seize the Day as a modernist novel offers a solution to the epistemological engulfment of Tommy Wilhelm as the protagonist.

\section{REFERENCES}

[1] Abrams, M.H. (1971). A Glossary of Literary Terms. 3rd ed. New York and London: Halt, Rinehart and Winston, Inc.

[2] Bellow, Saul. (1977). Seize the Day. USA: Penguin Books Limited.

[3] Bradbury, Malcolm, and James Mc Farlane, eds (1991). Modernism: a Guide to European Literature. London and New York: Penguin Books ltd.

[4] Brooker Peter. (1972). Modernism/Postmodernism. London and New York: Longman,

[5] Ciancio, Ralph. (1969). "The achievement of Saul Bellow's Seize the Day." Literature and Theology. Eds.Thomas F.Staly and Lester F.Zimmerman. U of Tulsa Dep. Of English monograph series 7.Tulsa, ok: U of Tulsa.

[6] Cuddon, J. A. (1977). A Dictionary of Literary Terms. U S A: Doubleday and Company, inc.

[7] Faulkner, Peter .(1977). Modernism: The Critical Idiom. Ed. John D.Jump. London: Methuen and Co Ltd.

[8] Lacey, A. R. (2005). A Dictionary of Philosophy. London: Taylor \& Francis.

[9] Levenson, Michael, ed. (2002). Modernism. Cambridge: Cambridge UP.

[10] Lewis, Barry. (2001)."Postmodernism and Literature (or: World Salad Days, 1960-90)." The Routledge Companion to Postmodernism. Ed. Stuart Sim. London and New York: Routledge.

[11] MacIntyre, Alasdair. (2003). "The Virtues, the Unity of an Human Life, and the Concept of a Tradition." From Modernism to Postmodernism. Ed. Lawrence Cahoone. Malden, Mass.

[12] Matz, Jesse. (2004). The Modern Novel: A Short Introduction. Malden, Mass: Blackwell.

[13] MacHale, Brian. (1983). Postmodernist Fiction. London: Routledge.

[14] Nicholls, Peter. (1995). Modernism: A Literary Guide. London: Macmillan.

[15] Ousby, Ian. (1996). Cambridge Paperback Guide to Literature in English. Cambridge: Cambridge UP.

[16] Reinhead, Julia., et al., eds. (2000). Norton Anthology of English Literature. 7 ed. Vol. 1. New York and London: ww. Norton and Company.

[17] Trotter, David. (1999). “The Modernist Novel.” The Cambridge Companion to Modernism. Ed. Michael Levenson. Cambridge: CUP, 70-99.

[18] Waugh, Patricia. (1988). Metafiction: The Theory and Practice of Self-conscious Fiction. London: Routledge.

Noorbakhsh Hooti is currently an Assistant Professor of English Language and Literature at Kermanshah Razi University, Iran. His main interests of research are drama, Short Story and Novel. He has been engaged in teaching English language and Literature for more than fifteen years. He holds Ph. D. in English Language and Literature, M. A. in English Language and Literature, and B.A in English Language and Literature. He has published a number of books, Research Projects, and articles in his areas of interest in academic journals.

Vahid Omrani is an instructor at Lorestan University, Khoram Abad, Iran. His main areas of research are Novel and drama. He holds a B. A. and M.A in English Language and Literature. 